\title{
ANALISIS KELAYAKAN SERTA PERANCANGAN APLIKASI WEBSITE PADA STARTUP DIGITAL CREATIVE FOTOGRAFI BERDASARKAN ASPEK PASAR, ASPEK TEKNIS DAN ASPEK FINANSIAL
}

\author{
Putri Maulani Fauzi, Endang Chumaidiyah*, Nanang Suryana \\ Program Studi Teknik Industri, Fakultas Rekayasa Industri, Universitas Telkom \\ Email: putrimaulanii@gmail.com; endangchumaidiyah@yahoo.co.id; \\ nanangsuryana@telkomuniversity.ac.id
}

Artikel masuk : 09-08-2019

Artikel direvisi : 07-10-2019
*Penulis Korespondensi

Artikel diterima : 24-11-2019

\begin{abstract}
Abstrak - Startup Digital Creative Fotografi merupakan suatu usaha jasa berbasis digital pada bidang fotografi. Bisnis ini merupakan usaha informal yang baru berdiri sekitar satu tahun. Usaha ini awalnya dibentuk oleh empat orang fotografer yang berdomisili di Bandung dengan melakukan pemasarannya melalui media sosial yaitu Instagram. Usaha ini berencana melakukan pengembangan usahanya dengan membuat website yang akan digunakan sebagai media pemasaran, komunikasi dan media untuk melakukan pemesanan oleh para konsumennya, serta sewa bangunan yang akan digunakan sebagai kantor bagi para tenaga kerjanya. Penelitian ini bertujuan untuk mengetahui kelayakan pengembangan usaha berdasarkan aspek pasar, aspek teknis, dan aspek finansial. Data pasar diperoleh dari hasil penyebaran kuesioner kepada penduduk Kota Bandung usia 15 - 34 tahun. Diperoleh pasar potensial sebesar 60,64\%, pasar tersedia sebesar 45,74\%, dan pasar sasaran sebesar 0,07\% dari pasar tersedia. Analisis aspek teknis dilakukan untuk mengetahui jumlah tenaga kerja, peralatan, serta sarana dan prasarana yang diperlukan dalam didirikannya usah ini. Hasil perhitungan finansial diperoleh nilai NPV sebesar Rp 289.803.474, nilai IRR sebesar 37\%, dan PBP selama 2,38 tahun. Nilai IRR > MARR yaitu 10,99\%, dan nilai NPV > 0, maka usaha ini dikatakan layak untuk dijalankan. Batas sensitivitas dari didirikannya usaha ini terhadap kenaikan biaya tenaga kerja langsung yaitu sebesar 21,95\%, penurunan demand sebesar 14,43\%, penurunan harga paket jasa sebesar $10,59 \%$, dan kenaikan biaya investasi sebesar $65,3 \%$.
\end{abstract}

Kata kunci: Analisis Kelayakan, Analisis Sensitivitas, IRR, NPV, PBP

\begin{abstract}
Digital Creative Startup Photography is a digital-based service business in the field of photography. This business is an informal business that has only been established for around a year. This business was originally formed by four photographers who live in Bandung by marketing it through social media, namely Instagram. This business will expand its business by creating a website that will be used as a marketing, communication, and media to place orders by its customers, as well as building leases that will be used as an office for its workers. This study aims to determine the feasibility of business development based on market aspects, technical aspects, and financial aspects. Market data obtained from the results of the distribution of questionnaires to residents of the city of Bandung aged 15-34 years. The potential market is $60.64 \%$, the available market is $45.74 \%$, and the target market is $0.07 \%$ of the available market. Analysis of technical aspects is carried out to determine the number of workers, equipment, facilities, and infrastructure needed in the establishment of this business. The financial calculation results obtained the NPV value of Rp. 289,803,474, IRR value of $37 \%$, and PBP for 2.38 years. IRR value> MARR is $10.99 \%$, and NPV value> 0 , so this business is said to be feasible to run. The sensitivity limit of the establishment of this business to an increase in direct labor costs is $21.95 \%$, a decrease in demand by $14.43 \%$, a decrease in the price of service packages by $10.59 \%$, and an increase in investment costs by $65.3 \%$.
\end{abstract}

Keywords: Feasibility Analysis, IRR, NPV, PBP, Sensitivity Analysis 


\section{PENDAHULUAN}

Perkembangan teknologi menjadi salah satu peluang dalam dunia bisnis. Internet dalam bisnis dapat digunakan untuk mendukung dalam menjalankan suatu strategi bisnis seperti pemasaran, penjualan, dan pelayanan terhadap customernya. Media online mampu mendukung perkembangan bisnis bagi pelaku bisnis untuk memperluas pasar.

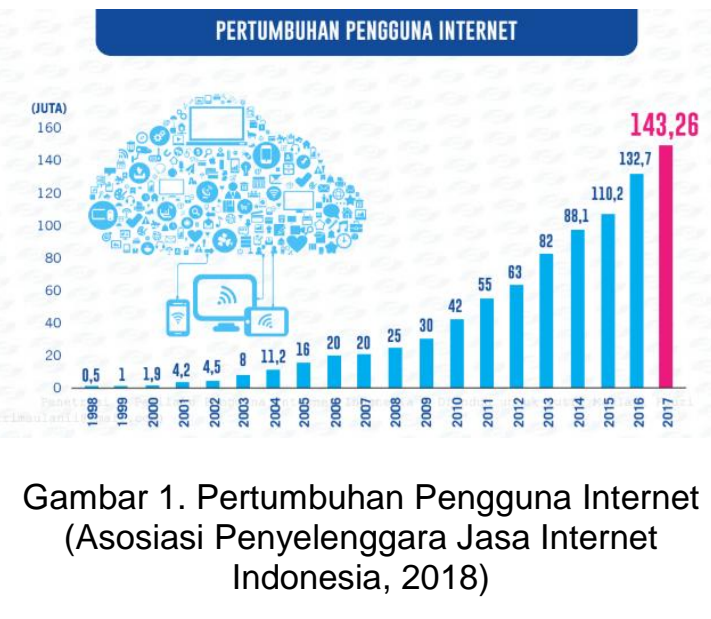

Penggunaan internet di Indonesia mengalami peningkatan dari tahun ke tahun, di mana pada tahun 2017 mencapai 143,26 juta (Gambar 1). Tingkat pengguna yang begitu besar menjadi peluang bisnis yang dapat digunakan oleh pelaku bisnis untuk melakukan dan membuka suatu bisnis baru. Peluang pengembangan e-commerce yang begitu besar mampu menciptakan lima model bisnis seperti classified, marketplace, shopping mall, online store B2C, dan online store(Indrajit, 2002; Suwarni, Sedyastuti, \& Mirza, 2019).

Tingginya pengguna internet juga berdampak pada lahirnya startup baru. Startup bisnis merupakan suatu bisnis yang baru berbasis teknologi. Biasanya startup bisnis adalah usaha yang baru didirikan dan masih dalam tahap pengembangan dalam menemukan pasar yang tepat di dalam kondisi ketidakpastian yang tinggi (Ries, 2011). Startup dalam menjaga eksistensinya masih mengalami banyak hambatan seperti sumber pendanaan yang kurang memadai (Saputra, 2015), pengelolaan sumber daya yang terbatas (Afdi \& Purwanggono, 2018; Collis, 2016), maupun kesulitan dalam mendapatkan pelanggan.

Startup Digital Creative Fotografi ini merupakan suatu usaha jasa berbasis digital pada bidang fotografi. Bisnis ini merupakan usaha informal yang baru berjalan sekitar satu tahun. Usaha ini dibentuk oleh empat orang fotografer yang berdomisili di Bandung dengan melakukan pemasarannya melalui media sosial yaitu Instagram. Usaha ini menawarkan personal photographer berupa jasa foto dan konsep pada pengambilan gambar bagi para konsumennya yang ingin didokumentasikan pada event seperti foto pra nikah, pernikahan, lamaran, acara ulang tahun, foto booklet, atau foto yang digunakan sebagai social media marketing seperti endorsement bagi para selebgram, foto untuk pemasaran suatu restaurant, pengambilan gambar berupa video, dan lain-lain. Startup Digital Creative Fotografi akan melakukan pengembangan usahanya dengan membuat website yang akan digunakan sebagai media pemasaran, media komunikasi serta media untuk melakukan order oleh para konsumennya.

Pengukuran kelayakan pengembangan dapat dilakukan berdasarkan aspek pasar, aspek teknis maupun aspek finansial (Dwiputra, 2017; Oktoyadi \& Wahyuni, 2019; Wirawan, Chumaidiyah, \& Aryani, 2017). Penelitian ini bertujuan menganalisis kelayakan pengembangan usaha fotografi berdasarkan aspek pasar, aspek teknis, aspek finansial bisnis, sensitivitas dan resiko yang akan di dapat. Hasil penelitian ini diharapkan dapat menjadi rekomendasi bagi Startup Digital Creative Fotografi dalam menentukan strategi pengembangan usaha ini.

\section{METODE PENELITIAN}

Tahap awal yang dilakukan yaitu melakukan perumusan masalah pada penelitian yang akan dilakukan, tujuan penelitian, serta pencarian teori-teori pada studi literatur dan studi lapangan. Adapun perumusan masalah dilakukan untuk mengidentifikasi masalah yang akan menjadi pokok dan latar belakang permasalahan yang akan dibahas dalam penelitian ini yaitu berupa analisis kelayakan pada Startup Digital Creative Fotografi berdasarkan aspek pasar, aspek teknis dan aspek finansial. Tahap selanjutnya yaitu melakukan pengumpulan dan pengolahan data pada aspek pasar, aspek teknis, dan aspek finansial. Setelah itu dilakukan analisis pada setiap aspek tersebut serta sensitivitas dan risiko pada usaha tersebut. Kemudian dilakukan analisis kelayakan dari usaha tersebut dapat dikatakan layak atau tidak.

\section{Studi Kelayakan}

Pengertian studi kelayakan bisnis adalah suatu penelitian yang terdiri dari beberapa aspek yang digunakan untuk mengambil keputusan apakah bisnis tersebut dapat dijalankan atau tidak yaitu dari aspek hukum, sosial ekonomi dan budaya, aspek pasar dan pemasaran, aspek teknis dan teknologi sampai dengan aspek manajemen dan keuangan (Lilis Sulastri, 2016). 
Dalam melakukan atau menyusun studi kelayakan bisnis, faktor-faktor yang perlu dinilai terdiri dari berbagai aspek yaitu aspek pemasaran, aspek teknis produksi, aspek manajemen, aspek lingkungan, dan aspek keuangan (Ibrahim, 2003).

Penyusunan studi kelayakan bisnis dibuat ketika pelaku bisnis akan melakukan hal-hal sebagai berikut (Suliyanto, 2010).

a. Merintis usaha baru

b. Mengembangkan usaha yang sudah ada

c. Memilih jenis usaha atau investasi/proyek yang paling menguntungkan

\section{Aspek Pasar}

Pengertian pasar yaitu pelaku atau orang orang yang mempunyai keinginan untuk puas, uang untuk berbelanja, dan kemauan untuk membelanjakannya. Terdapat tiga unsur penting yang terdapat dalam pasar yaitu orang dengan segala keinginannya, daya beli mereka, dan kemauan untuk membelanjakannya (Situmorang \& Dilham, 2007). Dalam aspek pasar dibahas mengenai besar pasar yang diminta dan pasar yang tersedia untuk merencanakan volume penjualan serta menganalisis persaingan untuk merencanakan strategi yang akan digunakan untuk memasarkan barang atau jasa yang ditawarkan pada usaha tersebut (Husen Sobana, 2018).

\section{Aspek Teknis}

Aspek teknis adalah aspek membahas proses pengembangan proyek teknis dan operasinya (Prasetya, Nugraha, \& Arijanto, 2013). Berdasarkan analisis ini juga dapat diperoleh penilaian awal rencana biaya investasi termasuk biaya pengembangan. Suatu investasi usaha sebaiknya ditunda terlebih dahulu apabila secara teknis tidak berjalan dengan baik meskipun menurut aspek pasar dikatakan layak dijalankan. Hal tersebut dikarenakan bisnis/usaha sering mengalami kegagalan karena tidak mampu menghadapi masalah-masalah teknis. Hal-hal yang perlu diperhatikan pada aspek teknis dan teknologi yaitu sebagai berikut (Suliyanto, 2010):
a. Penentuan lokasi bisnis
b. Penentuan luas produksi
c. Pemilihan mesin peralatan dan teknologi
d. Penentuan layout pabrik dan bangunan

\section{Aspek Finansial}

Keuangan adalah salah satu fungsi dari bisnis atau usaha yang bertujuan untuk memberi keputusan untuk berinvestasi, pendanaan dan dividen. Studi keuangan akan memberikan pemahaman mendalam mengenai arah bagaimana dana akan dialokasikan yang dapat dilakukan dalam dua bentuk yaitu untuk aktiva tetap (fixed assets) dan modal kerja (working capital) (Situmorang \& Dilham, 2007). Aspek biaya investasi dan biaya operasional merupakan dua jenis biaya yang mempengaruhi perhitungan kelayakan finansial suatu usaha (Suliyanto, 2010).

\section{Analisis Kelayakan Investasi}

Beberapa metode yang biasa digunakan untuk menilai analisis kelayakan investasi yaitu (Suliyanto, 2010):

a. Payback Period (PP)

Payback Period (PP) merupakan metode yang digunakan untuk menghitung lama periode yang diperlukan untuk mengembalikan uang yang telah diinvestasikan dari aliran kas masuk tahunan yang dihasilkan oleh proyek investasi tersebut. Investasi diterima apabila payback period lebih pendek dibandingkan payback maksimum. Sebaliknya jika payback period suatu investasi lebih panjang daripada period payback maksimum maka investasi tersebut dinyatakan tidak layak.

$P P=\frac{\text { Investasi kas bersih }}{\text { Aliran kas masuk bersih tahunan }}$

\section{b. Net Present Value (NPV)}

Net Present Value (NPV) digunakan untuk mengurangi kekurangan-kekurangan yang terdapat pada metode payback period. NPV merupakan metode yang dilakukan dengan cara membandingkan nilai sekarang dari aliran kas masuk bersih dengan nilai sekarang dari biaya pengeluaran suatu investasi. Jika hasil NPV positif berarti investasi akan memberikan hasil yang lebih tinggi dibandingkan rate of return minimum yang diinginkan. Jika nilai NPV negatif berarti investasi akan memberikan hasil yang lebih rendah dibandingkan rate of return minimum yang diinginkan, maka investasi sebaiknya ditolak.

$$
\text { Net Present Value }(N P V)=\sum_{t=0}^{n} \frac{\text { At }}{(1+k)^{t}}
$$

Keterangan:

$$
\begin{array}{ll}
\mathrm{k} & \text { : Discount rate yang digunakan } \\
\mathrm{At} & \text { : Cash flow pada periode } \mathrm{t} \\
\mathrm{N} & \text { : Periode yang terakhir dimana cash flow } \\
& \text { diharapkan }
\end{array}
$$

Kriteria penilaian untuk Net Present Value (NPV) adalah (Sobana, 2018):

1) Jika NPV > 0, usaha yang dijalankan layak untuk dilaksanakan.

2) Jika NPV < 0, usaha yang dijalankan tidak layak untuk dilaksanakan.

3) Jika NPV $=0$, usaha yang dijalankan tidak rugi dan tidak untung.

\section{c. Internal Rate of Return (IRR)}

IRR digunakan untuk mencari tingkat bunga yang menyamakan nilai sekarang dari arus kas 
yang diharapkan pada masa mendatang atau penerimaan kas dengan mengeluarkan investasi awal. Apabila IRR sama dengan tingkat discount, maka usaha yang dijalankan tidak mendapat untung atau rugi. Jika IRR < tingkat discount rate, maka usaha yang dijalankan tidak layak dilaksanakan. Adapun IRR > tingkat discount rate, maka usaha tersebut layak untuk dijalankan (Sobana, 2018).

\section{Analisis Sensitivitas}

Analisis sensitivitas merupakan suatu analisis yang digunakan untuk melihat pengaruh yang terjadi akibat keadaan yang berubah-ubah. Dalam analisis sensitivitas dicari nilai pengganti pada komponen biaya dan manfaat yang terjadi, yang masih memenuhi kriteria minimum kelayakan investasi atau masih mendapatkan keuntungan normal. Keuntungan normal terjadi apabila nilai NPV sama dengan nol (NPV $=0)$. Artinya, sampai tingkat berapa usaha yang akan dijalankan menoleransi peningkatan harga atau penurunan input dan penurunan harga atau jumlah output. Parameter harga jual produk, jumlah penjualan, dan biaya dalam analisis finansial diasumsikan tetap setiap tahunnya (ceteris paribus). Namun nyatanya ketiga hal tersebut dapat berubah-ubah sejalan dengan berjalannya waktu. Maka analisis sensitivitas diperlukan untuk mengetahui sampai berapa persen penurunan harga atau kenaikan biaya yang terjadi dapat mengakibatkan perubahan dalam kriteria kelayakan usaha dari layak menjadi tidak layak (Sobana, 2018).

\section{HASIL DAN PEMBAHASAN}

Berdasarkan dari pengumpulan data maka dilakukan analisis aspek aspek pasar, aspek teknis, aspek finansial bisnis, sensitivitas dan risiko untuk menentukan kelayakan pengembangan usaha Startup Digital Creative Fotografi.

\section{Aspek Pasar}

Penilaian aspek pasar berdasarkan hasil penyebaran kuesioner kepada 100 responden yang merupakan penduduk Kota Bandung dengan rentang usia 15 - 34 tahun. Estimasi pasar dari kuesioner didapatkan estimasi pasar potensial dari usaha ini yaitu sebesar $60,64 \%$ dari populasi sehingga diperoleh besar pasar sasaran sebanyak 557.536 orang. Besar pasar tersedia dari usaha ini yaitu sebesar $45,74 \%$ dari pasar potensial sehingga diperoleh besar pasar tersedia sebanyak 255.017 orang. Usaha ini membidik besar pasar sasaran sebesar $0,07 \%$ dari pasar tersedia sehingga diperoleh besar sasaran sebanyak 180 orang. Pada penelitian ini dilakukan proyeksi demand untuk lima tahun kedepan yang mengalami peningkatan sebesar $0,36 \%$ per tahun yang merupakan rata - rata laju pertumbuhan jumlah penduduk Kota Bandung dalam tiga tahun terakhir (Tabel 1).

Tabel 1. Proyeksi demand

\begin{tabular}{|c|c|c|c|c|c|}
\hline \multirow{2}{*}{ Jasa } & \multicolumn{5}{|c|}{ Demand } \\
\hline & 2020 & 2021 & 2022 & 2023 & 2024 \\
\hline $\begin{array}{l}\text { Photography } \\
\text { Package }\end{array}$ & 87 & 88 & 89 & 90 & 91 \\
\hline $\begin{array}{l}\text { Pre-wedding } \\
\text { Package }\end{array}$ & 29 & 30 & 31 & 32 & 33 \\
\hline $\begin{array}{l}\text { Wedding } \\
\text { Package } \\
\text { Social }\end{array}$ & 9 & 10 & 11 & 12 & 13 \\
\hline $\begin{array}{l}\text { Media } \\
\text { Package }\end{array}$ & 9 & 10 & 11 & 12 & 13 \\
\hline $\begin{array}{l}\text { Videography } \\
\text { Package }\end{array}$ & 46 & 47 & 48 & 49 & 50 \\
\hline Total & 180 & 185 & 190 & 195 & 200 \\
\hline
\end{tabular}

\section{Aspek Teknis}

Berdasarkan total waktu proses yang telah ditentukan pada proses bisnis maka diperoleh jumlah tenaga kerja yang dibutuhkan pada usaha ini yaitu sebanyak 8 orang tenaga kerja dimana terdiri dari 7 orang fotografer dan 1 orang admin. Kemudian diperhitungkan jumlah peralatan yang dibutuhkan berdasarkan besar demand dan jumlah tenaga kerja yang telah dihitung.

Lokasi usaha pada Startup Digital Creative Fotografi ini akan digunakan sebagai kantor. Kantor tersebut merupakan tempat dimana fotografer melakukan proses editing dari hasil pengambilan gambar. Selain itu terdapat studio yang dapat digunakan sebagai latar dalam pengambilan gambar apabila dibutuhkan. Lokasi usaha pada usaha ini merupakan bangunan sewa yang berada pada jalan Sukahaji, Bandung. Bangunan tersebut memiliki luas tanah sebesar $78 \mathrm{~m}^{2}$ dan luas bangunan sebesar $120 \mathrm{~m}^{2}$. Luas dan harga sewa bangunan merupakan hal yang menjadi pertimbangan dalam penentuan usaha ini.

Usaha ini akan melakukan pengembangan usahanya dengan membuat website yang akan digunakan sebagai media pemasaran, media komunikasi, dan media konsumen untuk melakukan order. Website yang akan dirancang tersebut dapat digunakan oleh tiga partisipan yang merupakan admin, tenaga kerja (fotografer), dan pelanggan. Pada website tersebut ditampilkan jasa-jasa yang ditawarkan pada usaha ini serta rinciannya. Pelanggan dapat melakukan order dan melihat riwayat order pada usaha ini melalui website yang akan dirancang ini. Berdasarkan hasil perancangan website pada Startup Digital Creative Fotografi, berikut user 
interface pada website yang telah dirancang (Gambar 2 dan Gambar 3)

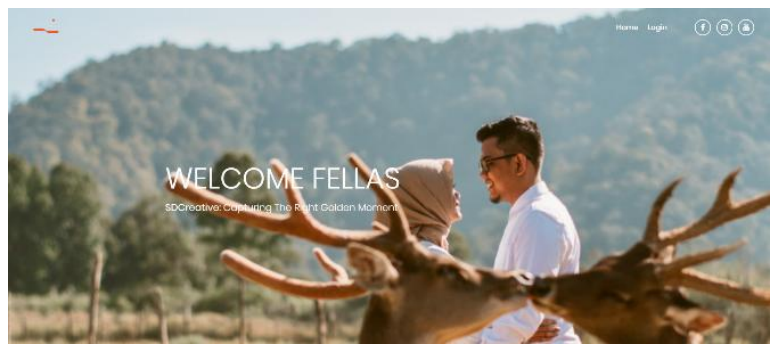

Gambar 2. User Interface Website (Home)

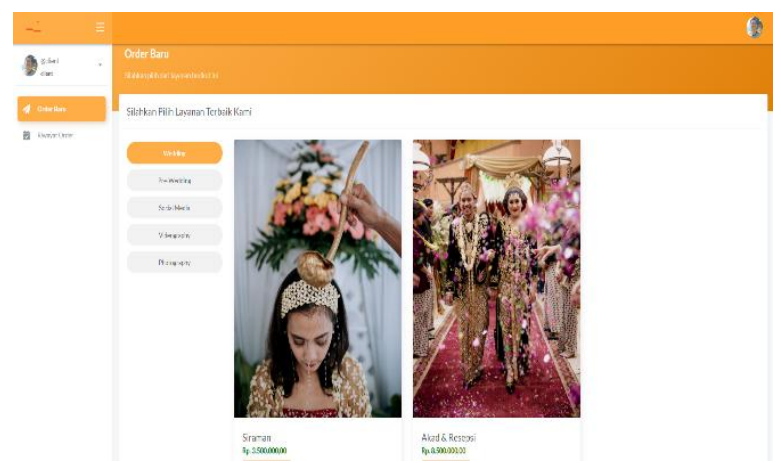

Gambar 3. User Interface Website (Setelah Login)

Setelah melakukan perancangan pada website, kemudian dilakukan uji implementasi dari website yang telah dirancang kepada beberapa pengguna sebagai admin, fotografer, dan pelanggan (Tabel 2). Hasil implementasi menunjukkan admin 1 sukses melakukan konfigurasi kategori, admin 2 sukses melakukan cek riwayat pemesanan, staff 1 sukses melihat detail order, pelanggan 1 sukses melakukan login/register, dan pelanggan 2 sukses melakukan order.

Tabel 3. Uji Implementasi Website

\begin{tabular}{lllc}
\hline No & Pengguna & \multicolumn{1}{c}{ Kegiatan } & Keterangan \\
\hline 1 & Admin 1 & $\begin{array}{l}\text { Melakukan } \\
\text { konfigurasi } \\
\text { kategori } \\
\text { Mengecek } \\
\text { riwayat } \\
\text { pemesanan }\end{array}$ & Sukses \\
2 & Admin 2 & $\begin{array}{l}\text { Melihat detail } \\
\text { order }\end{array}$ & Sukses \\
3 & Staff 1 & $\begin{array}{l}\text { Melakukan } \\
\text { login/register } \\
\text { Melakukan order }\end{array}$ & Sukses \\
5 & Pelanggan & Suksangan 2 & Suks \\
\hline
\end{tabular}

\section{Aspek Finansial}

Analisis aspek finansial akan menghasilkan kebutuhan dana investasi, perkiraan pendapatan, biaya operasional, proyeksi cash flow, NPV, IRR, dan Payback Period yang akan digunakan selanjutnya sebagai data dilakukannya analisis sensitivitas untuk mengetahui pengaruhnya terhadap tingkat kelayakan usaha yang dilakukan apabila terjadi perubahan variabel berupa biayabiaya yang dikeluarkan pelaku bisnis.

Biaya investasi dari pendirian usaha Startup Digital Creative Fotografi ini terdiri dari biaya peralatan, sewa bangunan, dan biaya pembuatan website. Total biaya investasi yang dibutuhkan yaitu sebesar Rp 300.110.000. Biaya operasional terdiri dari biaya langsung dan biaya tidak langsung. Biaya langsung merupakan biaya yang dikeluarkan untuk menghasilkan suatu output berupa produk atau jasa yang terdiri dari biaya bahan baku, biaya tenaga kerja langsung. Total biaya operasional pada usaha ini pada tahun ke-0 yaitu sebesar Rp 619.675.065 (Gambar 4).

Biaya operasional yang perlu dikeluarkan oleh usaha ini meningkat setiap tahunnya dikarenakan proyeksi demand setiap tahunnya mengalami peningkatan berdasarkan kenaikan jumlah penduduk Kota Bandung yang menjadi sasaran dari usaha ini. Peningkatan biaya tersebut juga terjadi karena adanya inflasi dimana kenaikan inflasi diasumsikan sama setiap tahunnya yaitu sebesar $3.32 \%$.

\section{Total Biaya Operasional}

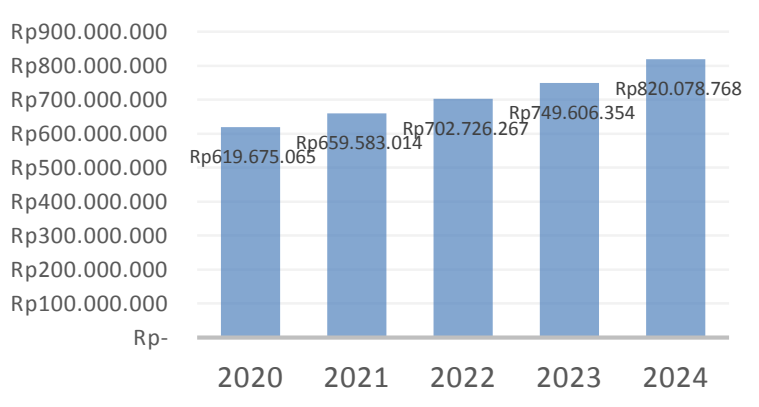

Gambar 4. Biaya Operasional

Kebutuhan dana merupakan dana yang dikeluarkan untuk biaya investasi pada usaha Startup Digital Creative Fotografi berdasarkan investasi tetap dan working capital (Tabel 3). Pendapatan pada usaha Startup Digital Creative Fotografi ini diperoleh dari harga jasa pada setiap package yang ada dikalikan dengan jumlah proyeksi demand pada usaha ini. Pendapatan mengalami peningkatan setiap tahunnya dikarenakan jumlah demand yang meningkat setiap tahunnya (gambar 5).

Metode yang digunakan untuk menilai kelayakan investasi pada usaha yang sedang dilakukan yaitu NPV, IRR, dan PBP. Untuk melakukan perhitungan pada kelayakan investasi 
ini diperlukan data cash out, cash in, dan net cash (Tabel 5).

Tabel 4. Kebutuhan Dana

\begin{tabular}{|c|c|c|}
\hline \multicolumn{3}{|c|}{ Total Project Cost (TPC) 2019} \\
\hline Investasi Tetap & $\mathrm{Rp}$ & $\overline{, 110,000}$ \\
\hline $\begin{array}{l}\text { Working Capital (perkiraan } \\
\text { biaya selama periode } 3 \\
\text { bulan) }\end{array}$ & $\mathrm{Rp}$ & $9,282,266$ \\
\hline SIUP & $\mathrm{Rp}$ & $2,700,000$ \\
\hline Merk Dagang & & 500,000 \\
\hline Total & $\mathrm{Rp}$ & 2,592,266 \\
\hline
\end{tabular}

\section{Estimasi Pendapatan}

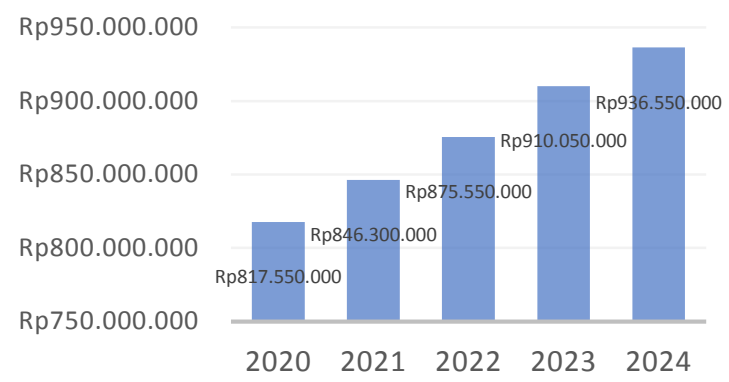

Gambar 5. Estimasi Pendapatan

Nilai interest rate diasumsikan berdasarkan rata-rata nilai suku bunga pinjaman bank-bank yang ada di Indonesia. Berdasarkan Tabel 5 dapat dilihat bahwa nilai NPV terakhir yang diperoleh yaitu sebesar $\mathrm{Rp}$ 289.803.474. Waktu periode yang dibutuhkan untuk mengembalikan nilai sisa uang dari investasi yaitu selama 2,38 tahun, dan nilai IRR yang didapat sebesar $37 \%$. Nilai tingkat MARR diasumsikan sebesar 10,99\%. Karena nilai IRR pada usaha ini lebih besar dibandingkan nilai MARR, maka usaha ini dapat dikatakan layak.

Tabel 5. Kelayakan Investasi

\begin{tabular}{lc}
\hline Interest Rate & $10.99 \%$ \\
\hline NPV & Rp 289,803,474 \\
PBP & 2.38 \\
IRR & $37 \%$ \\
\hline
\end{tabular}

\section{Analisis Sensitivitas}

Pengukuran sensitivitas dilakukan untuk menguji dan mengetahui efek yang terjadi apabila terjadi perubahan variabel-variabel biaya atau pendapatan yang terdapat dalam proyeksi finansial pada usaha ini. Variabel yang dirasa dapat mempengaruhi yaitu kenaikan biaya tenaga tenaga kerja langsung dan penurunan demand.
Perubahan persentase tersebut berdasarkan pada hasil IRR dan NPV. Rincian pengukuran sensitivitas dari kenaikan biaya tenaga kerja langsung dan penurunan demand pada usaha ini dapat dilihat pada Tabel 6, Tabel 7, Tabel 8, dan Tabel 9.

Tabel 6. Sensitivitas Kenaikan Biaya Tenaga Kerja Langsung

\begin{tabular}{lccc}
\hline & \multirow{2}{*}{ Awal } & \multicolumn{2}{c}{ Kenaikan Persentase } \\
$\mathbf{2 1 \%}$ & $\mathbf{2 2 \%}$ \\
\hline NPV & $\mathrm{Rp}$ & $\mathrm{Rp}$ & $\mathrm{Rp}$ \\
$\mathrm{IRR}$ & $289,803,474$ & $12,562,379$ & $(639,578)$ \\
MARR & $37 \%$ & $12 \%$ & $10.92 \%$ \\
Hasil & $10.99 \%$ & $10.99 \%$ & $10.99 \%$ \\
\multicolumn{2}{l}{$\begin{array}{l}\text { Biaya tenaga kerja langsung sensitif } \\
\text { terhadap kenaikan sebesar }\end{array}$} & $21.95 \%$ \\
\hline
\end{tabular}

Tabel 7. Sensitivitas Penurunan Jumlah Demand

\begin{tabular}{lccc}
\hline & \multirow{2}{*}{ Awal } & \multicolumn{2}{c}{ Penurunan Persentase } \\
& & $\mathbf{1 4 \%}$ & $\mathbf{1 5 \%}$ \\
\hline NPV & $\mathrm{Rp}$ & $\mathrm{Rp}$ & $\mathrm{Rp}$ \\
$\mathrm{IRR}$ & $37 \%, 803,474$ & $9,228,131$ & $(12,033,951)$ \\
MARR & $10.99 \%$ & $10.99 \%$ & $9.57 \%$ \\
Hasil & Layak & Layak & Tidak Layak \\
\hline $\begin{array}{l}\text { Demand sensitif terhadap penurunan } \\
\text { sebesar }\end{array}$ & & $14.43 \%$ \\
\hline
\end{tabular}

Tabel 8. Sensitivitas Penurunan Harga

\begin{tabular}{lccc}
\hline & \multirow{2}{*}{ Awal } & \multicolumn{2}{c}{ Penurunan Persentase } \\
& & $\mathbf{1 0 \%}$ & $\mathbf{1 1 \%}$ \\
\hline NPV & $\mathrm{Rp}$ & $\mathrm{Rp}$ & $\mathrm{Rp}$ \\
& $289,803,474$ & $16,105,944$ & $(11,148,930)$ \\
IRR & $37 \%$ & $12.68 \%$ & $9.79 \%$ \\
MARR & $10.99 \%$ & $10.99 \%$ & $10.99 \%$ \\
Hasil & Layak & Layak & Tidak Layak \\
\hline \multicolumn{2}{l}{$\begin{array}{l}\text { Harga paket jasa sensitif terhadap } \\
\text { penurunan sebesar }\end{array}$} & \\
\hline
\end{tabular}

Tabel 9. Sensitivitas Kenaikan Biaya Investasi

\begin{tabular}{llll}
\hline & \multicolumn{1}{c}{ Awal } & \multicolumn{2}{c}{ Kenaikan Persentase } \\
& & \multicolumn{1}{c}{$\mathbf{6 5 \%}$} & \multicolumn{1}{c}{$\mathbf{6 6 \%}$} \\
\hline NPV & $\mathrm{Rp}$ & $\mathrm{Rp}$ & $\mathrm{Rp}(3,102,221)$ \\
& $289,803,474$ & $1,335,744$ & \\
IRR & $37 \%$ & $11 \%$ & $10.80 \%$ \\
MARR & $10.99 \%$ & $10.99 \%$ & $10.99 \%$ \\
Hasil & Layak & Layak & Tidak Layak \\
\hline \multicolumn{2}{l}{$\begin{array}{l}\text { Biaya investasi sensitif terhadap } \\
\text { kenaikan sebesar }\end{array}$} & $65.3 \%$ \\
\hline
\end{tabular}




\section{Analisis Risiko}

Risiko - risiko yang mungkin terjadi pada usaha ini adalah sebagai berikut.

1. Konsumen membatalkan order

2. Demand menurun

3. Hasil tidak sesuai keinginan konsumen

4. Peralatan rusak/hilang

5. Pemotongan fee akibat kesalahan penyedia usaha

Setelah dilakukan pemetaan pada peta risiko, risiko yang paling membahayakan bagi perusahaan adalah hasil tidak sesuai dengan keinginan pelanggan yang dapat mengakibatkan perusahaan mengalami pemotongan fee akibat dari risiko tersebut. Risiko tersebut dapat terjadi akibat tidak lancarnya komunikasi konsumen dengan stakeholder sehingga menimbulkan kesalahpahaman keinginan konsumen. Pencegahan risiko pencegahan dengan melakukan komunikasi yang baik dan melakukan perjanjian di awal. Perjanjian tersebut berupa penjelasan layanan yang didapatkan oleh konsumen disesuaikan dengan keinginan konsumen tersebut.

\section{KESIMPULAN}

Berdasarkan dari hasil penelitian yang telah dilakukan diperoleh perancangan website yang mempermudah pelanggan dalam melakukan order serta melacak riwayat order yang telah dilakukan, Pengembangan yang dilakukan pada usaha ini berupa disewanya bangunan yang digunakan sebagai kantor, investasi barangbarang yang dibutuhkan, dan aspek teknis lainnya yang dibutuhkan dalam bisnis tersebut berdasarkan besar pasar yang menjadi target pada usaha tersebut. Usaha tersebut dikatakan layak berdasarkan dari perhitungan pada aspek finansial sehingga diperoleh nilai NPV $>0$ yaitu sebesar Rp 289.803.474, nilai IRR sebesar 37\% lebih besar dari nilai MARR sebesar 10,99\%, dan nilai PBP sebesar 2,38 tahun. Usaha Startup Digital Creative Fotografi paling sensitif terhadap penurunan harga paket jasa dibandingkan variabel lainnya dimana tingkat sensitifitasnya yaitu sebesar $10,59 \%$. Usaha menjadi tidak layak apabila mengalami penurunan harga paket jasa sebesar 10,59\%. Risiko yang paling membahayakan bagi perusahaan dari risiko-risiko yang mungkin terjadi yaitu hasil tidak sesuai dengan keinginan pelanggan yang dapat mengakibatkan perusahaan mengalami pemotongan fee akibat dari risiko tersebut

\section{DAFTAR PUSTAKA}

Afdi, Z., \& Purwanggono, B. (2018). Perancangan Strategi Berbasis Metodologi Lean Startup untuk Mendorong Pertumbuhan Perusahaan Rintisan Berbasis Teknologi di Indonesia.
Industrial Engineering Online Journal, 6(4), $1-13$.

Asosiasi Penyelenggara Jasa Internet Indonesia. (2018). Infografis; Penetrasi \& Perilaku Penguna Internet Indonesia survey 2017. Retrieved from https://apjii.or.id/survei2017

Collis, D. (2016). Lean strategy. Harvard Business Review, 94(3), 62-68.

Dwiputra, G. A. (2017). Analisis Kelayakan Pengembangan Usaha Rumah Makan Krebo Jantan. Jurnal Sistem Dan Manajemen Industri, 1(2), 85-90.

Ibrahim, H. M. Y. (2003). Studi kelayakan bisnis. Jakarta: PT Rineka Cipta.

Indrajit, R. E. (2002). Konsep dan Aplikasi Ebusiness. Yogyakarta: Andi Offset.

Lilis Sulastri, L. (2016). Studi Kelayakan Bisnis untuk Wirausaha. LGM-LaGood's Publishing.

Oktoyadi, O., \& Wahyuni, S. (2019). Kelayakan Pengembangan Bisnis E-Marketplace Perjalanan Ibadah Umrah Pada PT. Sarana Transwisata Teknologi. Jurnal Riset Perbankan Manajemen Dan Akuntansi, 3(2), 132-143.

Prasetya, A. T., Nugraha, C., \& Arijanto, S. (2013). Analisis Kelayakan Bisnis Kertas Berbahan Baku Rumput Laut Sebagai Alternatif Bahan Baku Pada Industri Kertas. Reka Integra, 1(3), 139-151.

Ries, E. (2011). The Lean Startup: How Today's Entrepreneurs Use Continuous Innovation to Create Radically Successful Businesses. Crown Business.

Saputra, A. (2015). Peran Inkubator Bisnis dalam Mengembangkan Digital Startup Lokal di Indonesia. CALYPTRA, 4(1), 1-24.

Situmorang, S. H., \& Dilham, A. (2007). Studi Kelayakan Bisnis. Medan: USU Press.

Sobana, H. D. (2018). Studi Kelayakan Bisnis. Bandung: Pustaka Setia.

Suliyanto. (2010). Studi Kelayakan Bisnis. Yogyakarta: Andi.

Suwarni, E., Sedyastuti, K., \& Mirza, A. H. (2019). Peluang dan Hambatan Pengembangan Usaha Mikro pada Era Ekonomi Digital. IkraIth Ekonomika, 2(2), 29-34.

Wirawan, F., Chumaidiyah, E., \& Aryani, S. (2017). Analisis Kelayakan Pembukaan Cabang Baru Bisnis Usaha Kecil Menengah Peyek Belut Sido Urip Secara Online Dan Offline Di Kota Yogyakarta. EProceedings of Engineering, 4(3). 